Provided for non-commercial research and education use. Not for reproduction, distribution or commercial use.

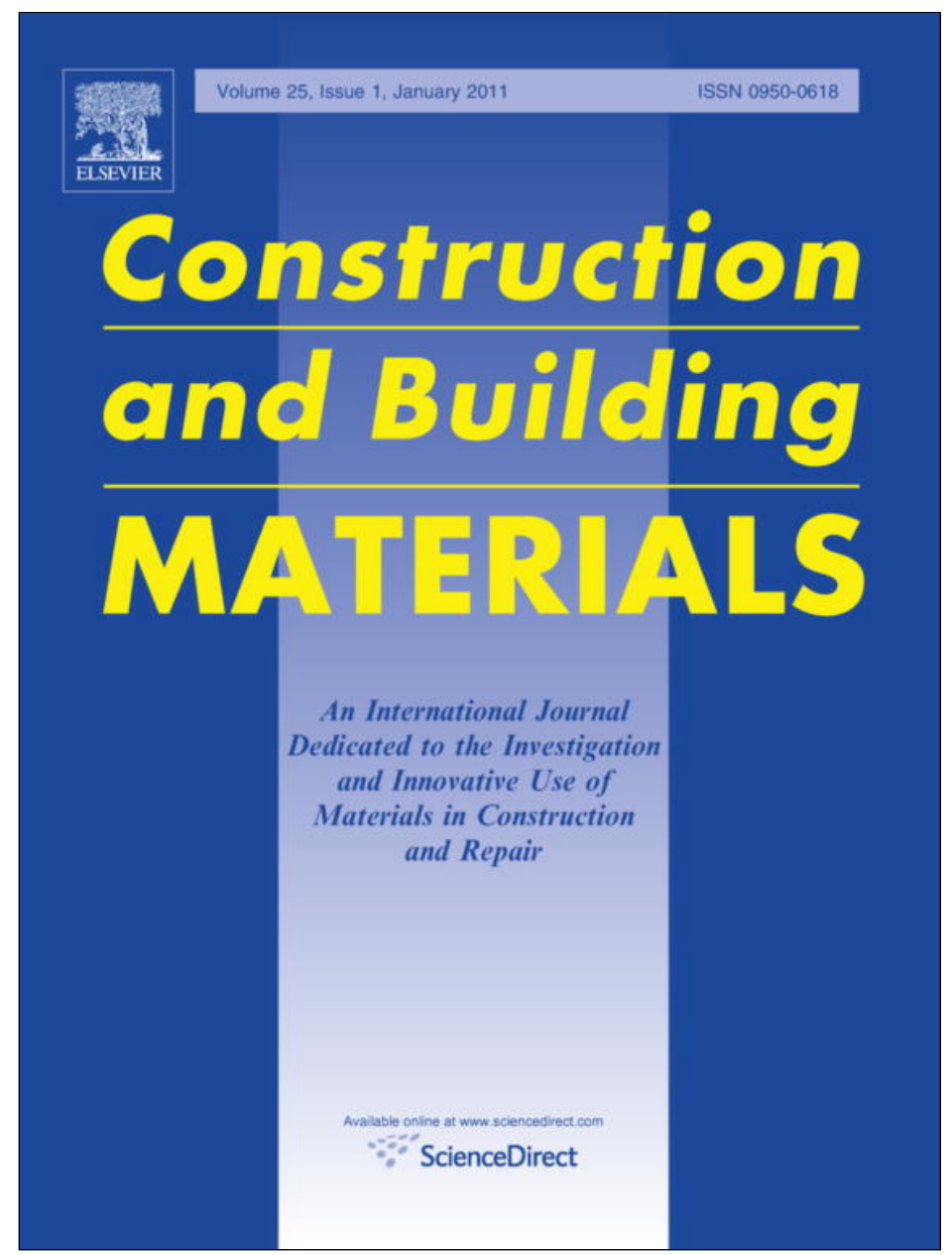

(This is a sample cover image for this issue. The actual cover is not yet available at this time.)

This article appeared in a journal published by Elsevier. The attached copy is furnished to the author for internal non-commercial research and education use, including for instruction at the authors institution and sharing with colleagues.

Other uses, including reproduction and distribution, or selling or licensing copies, or posting to personal, institutional or third party websites are prohibited.

In most cases authors are permitted to post their version of the article (e.g. in Word or Tex form) to their personal website or institutional repository. Authors requiring further information regarding Elsevier's archiving and manuscript policies are encouraged to visit:

http://www.elsevier.com/copyright 
Review

\title{
Earth construction: Lessons from the past for future eco-efficient construction
}

\author{
F. Pacheco-Torgal ${ }^{\mathrm{a}, *}$, Said Jalali ${ }^{\mathrm{b}, 1}$ \\ ${ }^{a}$ University of Minho, C-TAC Research Unit, 4800 Guimarães, Portugal \\ ${ }^{\mathrm{b}}$ University of Minho, Department of Civil Engineering, 4800 Guimarães, Portugal
}

\section{A R T I C L E I N F O}

\section{Article history:}

Received 24 June 2011

Received in revised form 3 October 2011

Accepted 4 October 2011

\section{Keywords:}

Earth construction

Rammed earth

Adobe

Cob

Energy

Wastes

Indoor air quality

\begin{abstract}
A B S T R A C T
Earth construction has received in the last decade an increased attention by the scientific community illustrated by a tenfold increase of the published research articles when compared to the previous decade. Earth construction has a major expression in less developed countries, however, the mimetic temptations towards more polluting construction techniques based on reinforced concrete and fired bricks are likely to favor a change towards a clear unsustainable pattern. In order to disclosure and highlight the importance of earth construction, this article reviews some of the environmental benefits associated with it. It includes an overview about its past and present. It also includes a review about economic issues, nonrenewable resource consumption, waste generation, energy consumption, carbon dioxide emissions and indoor air quality.
\end{abstract}

(c) 2011 Elsevier Ltd. All rights reserved.

\section{Contents}

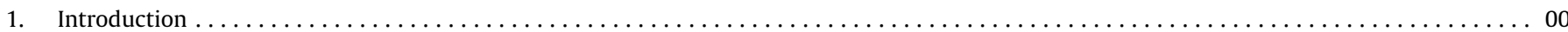

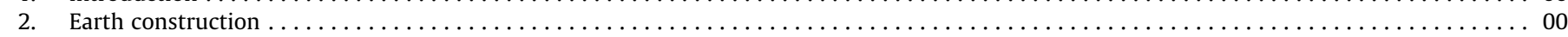

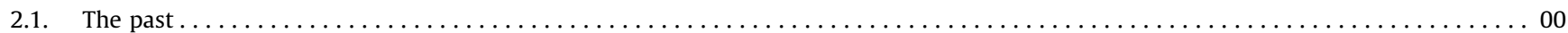

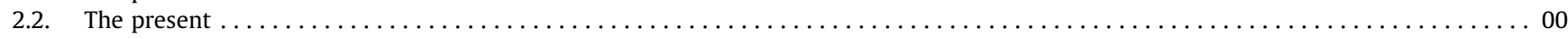

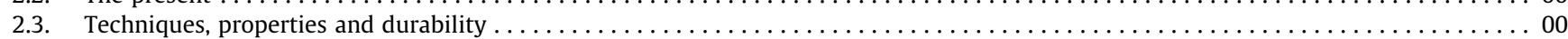

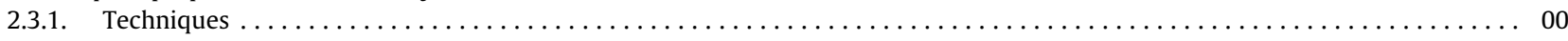

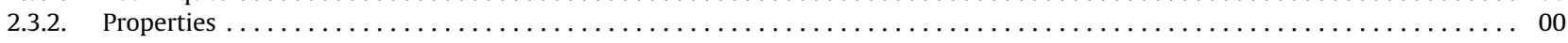

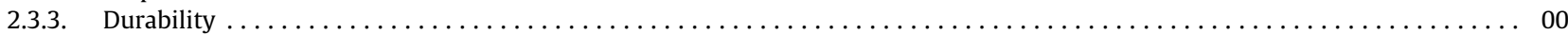

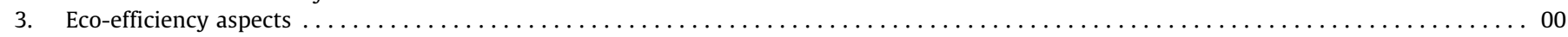

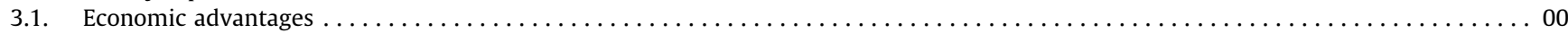

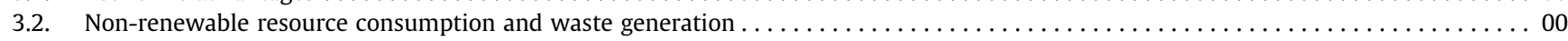

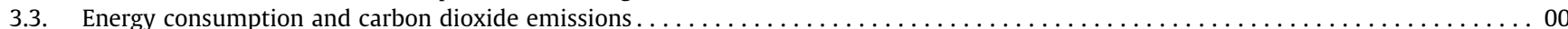

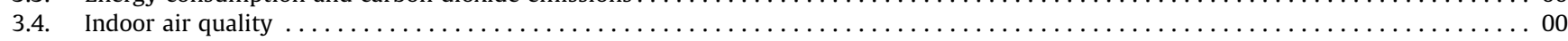

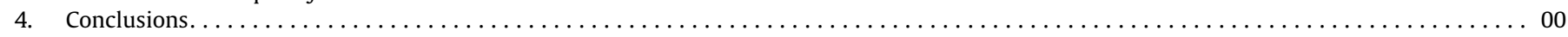

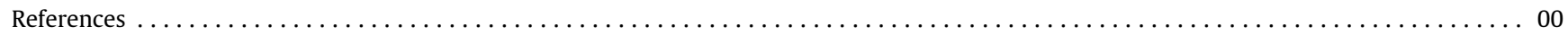

\section{Introduction}

Unlike other species who seek a balance with nature that will ensure their survival, mankind concerns only with the immediate

\footnotetext{
* Corresponding author.

E-mail addresses: torgal@civil.uminho.pt (F.Pacheco-Torgal), said@civil.uminho.pt (S. Jalali)

1 Tel.: +351 253 510200; fax: +351253510213.
}

satisfaction of their "needs" regardless that they may cause the exhaustion and the collapse of the ecosystem which they are an integral part, and this despite the fact that scientific community have been alerting for some time to the urgency of this problem [1-4]. The construction industry is one of the largest and most active sectors throughout Europe representing 28.1\% and $7.5 \%$ of employment respectively in the industry and in the European economy. With an annual turnover of 1200 billion euros, this sector represents $25 \%$ of all European industrial production, being the 
largest exporter with $52 \%$ market share. In world terms the construction industry will keep on growing at a fast pace. For instance China will need 40 billion square meters of combined residential and commercial floor space over the next 20 years - equivalent to adding one New York every 2 years or the area of Switzerland [5]. Environmentally speaking, this industry accounts for $30 \%$ of carbon dioxide emissions; in addition the global construction industry consumes more raw materials (about $3000 \mathrm{Mt} / \mathrm{year}$, almost $50 \%$ by weight) than any other economic activity, which shows a clearly unsustainable industry. The foreseeable increase in world population (by 2030 is expected to increase by more than 2000 million people) and the needs in terms of buildings and other infrastructure, would further increase the consumption of nonrenewable materials, as well as waste production. Therefore, the use of more sustainable construction materials and construction techniques represent a major contribution to the eco-efficiency of the construction industry and thus to a more sustainable development. In the last decade almost one hundred research articles related to this subject have been published in Scopus journals mostly related to rammed earth. This is just a small fraction (less than $10 \%$ ) of the research articles published about Portland cement concrete in the same period (the largest-volume manufactured product on earth [6] and responsible for $5 \%$ do world $\mathrm{CO}_{2}$ emissions), but it represents a tenfold increase compared to the research articles concerning earth construction publish in the 1990s. This means that more and more research efforts are being dedicated to transform the current building industry into a more sustainable one. Earth construction assumes in this particular context, an environmental advantage that makes it extremely competitive when compared to conventional materials and construction techniques. The majority of investigations carried out in this field are mostly related to the seismic response of earth buildings, mechanical properties of earth masonry and more recently about thermal and hygrothermal performance. The authors only found one review paper about the selection of soils [7]. The present manuscript reviews important aspects related to earth construction. It addresses economic advantages, non-renewable resource consumption, waste generation, energy consumption, carbon dioxide emissions, toxicity and indoor air quality.

\section{Earth construction}

\subsection{The past}

There is no consensus about the date when man began to use earth construction. Minke [8] mentioned this may have happened over 9000 years ago, basing its beliefs on the fact that earth blocks (adobe) based dwellings discovered in Turkmenistan dated from a period between 8000 and 6000 BC. Other authors [9] mentioned that the use of earth for construction purposes dates from the period of El-Obeid in Mesopotamia (5000-4000 BC). According to Berge [10] the oldest adobe blocks, which were discovered in the Tigris River basin date back to $7500 \mathrm{BC}$ so earth construction could have been used for more than 10,000 years. It is not very relevant, whether the earth construction began more than 9000 or over 10,000 years ago but its not far from the truth that the earth construction begin with the beginning with the start of early agricultural societies, a period whose current knowledge dates from 12,000 to 7000 BC. There are countless cases of earth buildings which were build 1000 years ago and made it to the XXI century. Even the Great Wall of China whose construction began about 3000 years ago has extensive sections built on rammed earth. Evidence show the use of earth construction by the Phoenicians in the Mediterranean basin including Carthage in 814 BC. The Horyuji Temple in Japan has rammed earth walls built 1300 years ago
[11]. This author refers the existence of rammed earth based buildings in the Himalayan region built in XII century. Adobe based buildings structures are common in Central America. The ruins of the city of Chanchán in Peru are among the most ancient earth based constructions [12]. The village of Taos in New Mexico is another example of ancient earth constructions (1000-1500 AC). Another good example is the city of Shibam in Yemen with earth buildings up to 11 floors that were built 100 years ago [13].

\subsection{The present}

Currently almost 50\% of the world's population lives in earth based dwellings [14]. The majority of earth construction is located in less developed countries, however, this kind of construction can also be found in Germany, France or even the UK that has an excess of 500,000 earth based dwellings. Earth construction has also increase substantially in US, Brazil and Australia largely due to the sustainable construction agenda, in which the earth construction assumes a key role. The French laboratory CRATerre, founded in 1979 and linked to the School of Architecture in Grenoble, which acquired an institutional dimension in 1986 through the recognition of the French Government, was capable to maintain a strong and steady action in the promotion of earth construction. Houben et al. [15] mention the success of an educational project undertaken in CRATerre, consisting of a scientific workshop with over 150 interactive experiences that in just 4 years had been attended by 11,000 visitors. As for Germany, Schroeder et al. [16] report the existence of vocational training on earth construction as well as courses that confer the Expert title in this area. Three universities offer earth construction courses respectively the University of Kassel, the University of Applied Sciences in Potsdam and the University of Weimar (Bauhaus). Earth construction is not only dependent on adequate training but also on specific regulations.

Several countries already have earth construction related standards. In Germany the first Earth Building Code dates back to 1944, but only in 1951 with DIN 18951, these regulations have been put into practice. In 1998 the German Foundation for the Environment disclosed several technical recommendations known as the "Lehmbau Regeln" [17]. Over the years they have been adopted by all the German states with the exception of Hamburg and Lower-Sáxony. A revised version of the "Lehmbau Regeln" passed in 2008. Australia was one of the first countries to have specific regulations on earth construction. The Australian regulations were published in 1952 by the Commonwealth Scientific and Industrial Research Organization (CSIRO) under the designation of "Bulletin 5". This document has been revised in 1976, 1981, 1987 and 1992. In 2002 this document has been replaced by the Australian Earth Building Handbook [18]. In 1992 the Spanish Ministry of Transport and Public Works published a document entitled "Bases for design and construction with rammed earth" to support not only rammed earth but also adobe based buildings. Recently Delgado and Guerrero [19] stated that earth construction is not yet regulated, posing several drawbacks such as the need to contract a building insurance during the 10 year warranty period. The United States has no specific regulations related to earth construction; but seismic regulations must be addressed by these constructions. Since 1991 New Mexico has a state regulation concerning rammed earth and adobe based constructions. New Zealand has one of the most advanced legal regulations on earth construction which is structured in three distinct parts:

NZS 4297:1998 - engineering design and earth buildings establishes performance criteria for mechanical strength, shrinkage, durability, thermal insulation and fire resistance; NZS 4298:1998 - materials and workmanship for earth buildings - defines requirements for materials and workmanship; 
NZS 4299:1998 - earth buildings not requiring specific design this part is applicable for buildings with less than $600 \mathrm{~m}^{2}$ (or $300 \mathrm{~m}^{2}$ per floor) and provides constructive solutions for walls, foundations and lintels. In New Zealand the earth building regulations are dependent on the building height. For heights of less than $3.3 \mathrm{~m}$ there is no need for a specific project, although the earth walls of should respect the provisions of NZS 4298:1998. As to the buildings with a height between 3.3 and $6.5 \mathrm{~m}$ shall be designed in accordance with NZS 4297:1998 [11]. Since 2001 Zimbabwe adopted a regulation based on the "Code of Practice for Rammed Earth Structures" [20], which is composed by six sections: (1) materials; (2) formwork; (3) foundations; (4) wall design according to compressive strength, water absorption and erosion; (5) masonry structural stability; (6) details and finishes. Shittu [21] mention the following constraints of earth construction: lack of skilled craftsmanship; absence of earth related courses and most of all the fact that earth construction are associated with low income status.

\subsection{Techniques, properties and durability}

\subsubsection{Techniques}

Earth construction encompasses several techniques such as, the most usual being:

- wattle and daub;

- cob;

- rammed earth (including earth projection);

- earth bricks (adobe) or compressed earth blocks (CEB);

In the wattle and daub technique the earth is pressed against a woven lattice of wooden strips used for almost 6000 years [22]. The Portuguese technique "tabique" [23] is some how similar to wattle and daub. As to the cob technique it involves mixing earth with straw and water to form layer by layer masonry walls [24]. Rammed earth means the compaction of moist earth (stabilized or not) inside a wooden formwork, although nowadays in Europe the steel formworks are replacing the wooden ones. In the earth projection technique the earth is previously stabilized and then it is projected against an inside formwork layer as it happens in shotcrete works. Hybrid earthen wall system that combines elements of rammed earth, cob and wattle and daub have been recently used in Portugal (Fig. 1). Adobe is a very simple earth building technique being the reason most ancient construction were made of adobe [25]. The word adobe comes from the Arab "attob" which means sun-dried brick [26]. The production of adobe bricks consists of filling wooden molds with moist earth which are then placed in the sun to dry. When the adobe dries shrinkage cracks could appear in its surface, so some authors $[27,28]$ suggest the use of straw or other vegetable fibers to prevent this. However, this position is not unanimous because vegetable fibers could rot leading to the appearance of fungi. The CEB represent an evolution of the adobe bricks by using a specific device to compress the earth inside a mold. The pressure can be carried out manually or mechanically. The earth consistency is similar to that used in rammed earth allowing obtaining earth blocks that are heavier and more resistant than adobe bricks. The first machine used to make CEB was the CINVA-Ram created by Raul Ramirez in the International American Housing Centre (CINVA) in 1956 [30]. Several other block making machines are also used like the Astram developed in the mid1970s ate Centre for Application of Science and Technology for Rural Areas in India, the CETA-Ram which is a modified CINVARam developed in 1976 at the Centre of Appropriate Technical Experimentation in Guatemala [29], the multi-block Brepak developed in 1980 at Building Research Establishment at Watford,

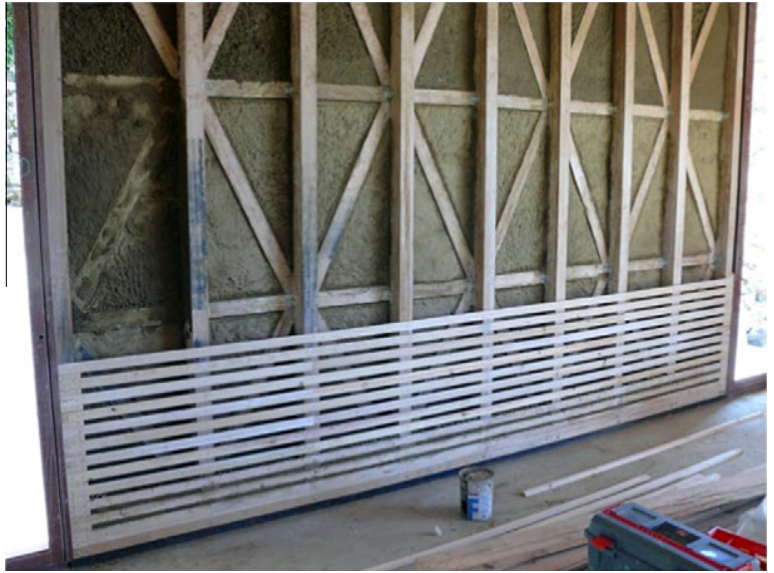

Fig. 1. Hybrid earthen wall system.

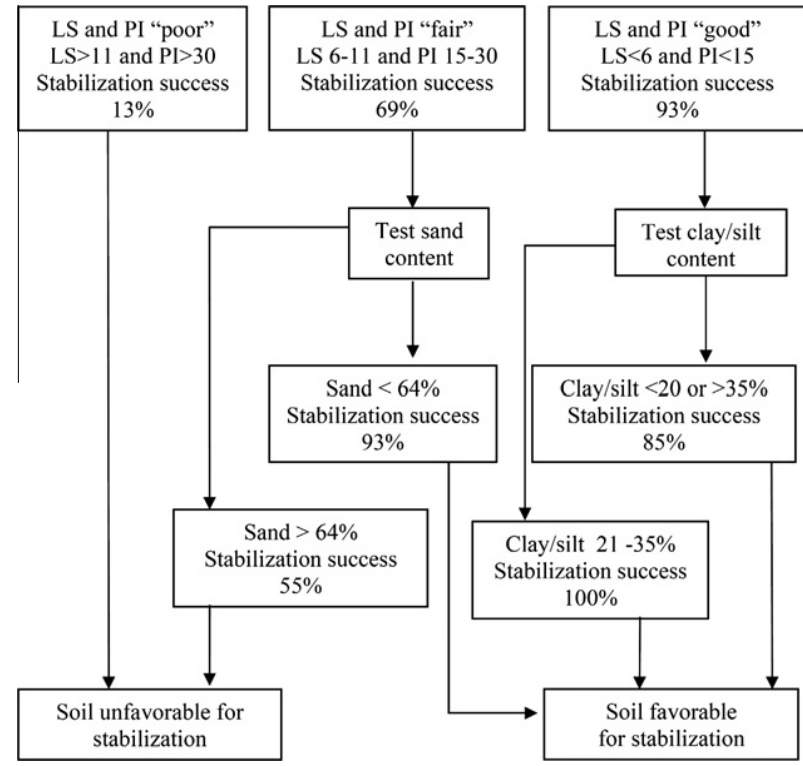

Fig. 2. Procedures for determining soil favorability for stabilization [31].

England [30], the CTA Triple-Block Press developed in 1982 at the Centre for Appropriate Technology in Paraguay and others.

\subsubsection{Properties}

The soil used in earth construction consists only in its mineral phase excluding the organic phase usually present in the first layers. This phase consists of mineral particles including clays, silts and sandy material, which are mixed together in varying proportions. The soil stabilization means changing the soil characteristics in order to improve its mechanical or physical behavior. The stabilization processes aim at the reduction of the soil plasticity, improvement its workability and also the resistance to erosion. Burroughs [31] analyzed 104 soil types, compacted and stabilized with lime or cement in a total of 219 mixtures. According to this author a soil could be considered suitable for stabilization if its compressive strength exceeds $2 \mathrm{MPa}$ (Fig. 2). Molasses, cow-dung and saw dust could also be used to stabilize adobe bricks [32]. Binici et al. [33] shows that using straw fibers in adobe bricks reduces the compressive strength. Nevertheless, the compressive strength is dependent on the brick dimensions [34]. Piattoni et al. [35] used $(15 \times 23 \times 13) \mathrm{cm}$ adobe bricks with straw reaching an average strength of $2.5 \mathrm{MPa}$. Silva et al. [36] studied the nests of the "andorinha-dos-beirais" bird concluding that a mixture of clay 
and polysaccharide/sugar is responsible for its high strength and high durability, suggesting that this knowledge could help enhanced earth construction. Unfortunately, the use of earth construction in seismic regions is not possible without a reinforced concrete structure $[37,38]$ reducing its eco-efficiency. MacDougall [39] used interviews and site inspections to show that straw bale construction and rammed earth construction are gaining growing interest in UK. The same authors reveal that lack of scientific data and lack of experience by the mainstream construction industry in using these materials remain barriers to be overcome. Goodhew and Griffiths [40] shows that $60 \mathrm{~cm}$ thickness cob walls have a thermal insulation which is twice the minimum of UK thermal requirements. Other authors $[39,41]$ show that straw construction complies with building regulations and the UK climate being a feasible option for this country. Williams et al. [42] also show that thermal performance of earth block masonry meet current UK Building Regulation requirements. The use of corns cob in Portuguese earth construction technique "tabique" shows adequate thermal properties [43]. One of the most interesting features of earth walls is not thermal insulation but its high thermal inertia, i.e., the ability to store and manage heat. Thermal inertia of earth walls, however, is a subject that still deserves further investigations [44,45]. According to Morton [46] 63-36 cm thickness earth walls show a sound reduction índex (SRI) between $46 \mathrm{db}$ and $57 \mathrm{db}$ which compare in a favorable manner with the SRI performance of $11 \mathrm{~cm}$ thickness fired clay bricks walls ( $35 \mathrm{db}$ ). The presentation of some disadvantages of earth construction is also in order [47]:

(1) Less durable as a construction material compared to conventional materials.

(2) Earth construction is labor intensive.

(3) Mud houses behave poorly in the event of earthquakes.

(4) Structural limitations.

(5) Need high maintenance.

(6) Professionals make less money from earth building projects.

(7) Special skills needed for plastering.

(8) Loam is not a standardized building material.

(9) Need higher wall thickness.

(10) Suitable only for in situ construction.

The presence of triatomine bugs and other pests inside earth walls deserves some concern [48]. According to Little and Morton [49] this aspect is only an issue if walls has been neglected and they are suffering from severe erosion. Other authors [50] recommend the use of bactericidal mixtures to prevent this problem.

\subsubsection{Durability}

The durability of earth construction is illustrated by the fact that some of these buildings last for hundreds of years. Durability has also been assessed by accelerated aging tests and more recently from monitoring experimental sections of earth masonry built a dozen years ago. The main mechanism responsible for the erosion of earth walls have to do with the kinetic energy of the impact of rainfall [51]. This justifies the worst durability behavior of earth walls oriented to the South, a direction usually associated with wind based rain. Other authors [52] mentioned that the rain does not always have an erosive effect on the earth walls which only happens for rain intensities above $25 \mathrm{~mm} / \mathrm{m}$. Bui et al. [53] evaluated the performance of 104 sections of rammed earth masonry with and without stabilization, which were exposed during for 20 years to natural climatic conditions (Fig. 3). The durability of earth buildings is also dependent on appropriate maintenance and repairs that are compatible with the original construction [49].

\section{Eco-efficiency aspects}

\subsection{Economic advantages}

For less developed countries the cost-efficiency aspect remains of paramount importance. Zami and Lee [54] quotes several authors for whom "earth construction is economically beneficial", nevertheless one cannot take this as a guaranteed truth because the economics of earth construction depends on several aspects such as: construction technique, labor costs, stabilization process, durability, repair needs. Williams et al. [42] mentioned that the materials used in earth construction in UK have not a significant impact in the final cost. These authors state that production and construction costs represent the most important part because earth construction is labor intensive. However, this is not the case in less developed countries in which labor is available for a very low cost. According to Sanya [55] this provides a very important way to create decentralized job creation. In these countries the cost-efficiency is dependent on the nature and the amount of binder used in the stabilization process.

\subsection{Non-renewable resource consumption and waste generation}

The use of soil for earth construction cannot be regarded as a use of a renewable resource; however, one must recognize that is very different from the extraction of raw materials needed for the construction materials used in conventional masonry. This is because generally the soil used in earth construction is located
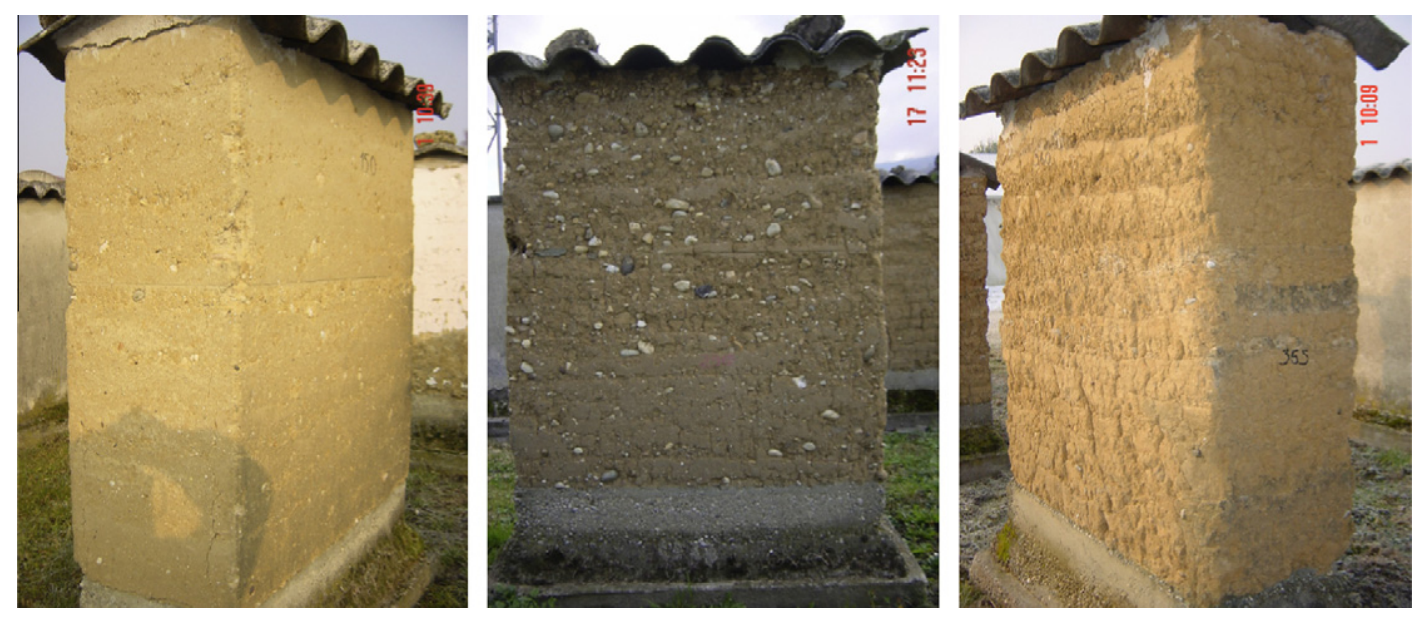

Fig. 3. Rammed earth masonry sections exposed during 20 years to natural climatic conditions. (a) Wall made with soil stabilized with $5 \%$ lime; (b) wall made with soil without stabilization (mixed soil); and (c) wall made with soil without stabilization [53]. 
immediately below the organic layer of the soil. If we assume that the building is made with soil located in the vicinity there is no pollution associated to its transportation. This very different of conventional masonry in which concrete blocks and ceramic bricks are always very distant of construction sites thus implying high transport distances responsible for the emissions of green house gases (GHGs). Regarding earth construction wastes they can simply be deposited at the site of its extraction without any environmental hazard involved. Even when the soil is stabilized with cement or lime, it can be reused in this type of construction, so we may thus consider earth construction hardly generates any waste. As a comparison the traditional ceramic brick masonry implies a relevant amount of wastes because the use of broken pieces takes place quite often in this kind of masonry. According to Morton [46] earth construction could reuse the 24 million tones of waste soil produced every year in UK.

\subsection{Energy consumption and carbon dioxide emissions}

The increasing demand for worldwide energy is a major cause for the unsustainable development of our Planet. Between 2007 and 2030 energy demand should have grown about $40 \%$ to 16.8 billion ton of equivalent petroleum-TEP [56]. The rise in energy consumption has two main reasons, the increase in world population and the fact that there is an increasing number of people with access to electricity. Currently 1.5 billion people still have no access to electricity [57]. Beyond what energy consumption means is in terms of using non-renewable fossil materials, the highest environmental impact of energy consumption, has to do with carbon dioxide emissions, generated during the burning of coal and gas for electricity generation in power stations. Given that buildings consumes throughout its life cycle, more than $40 \%$ of all energy produced [58], we can easily see the high energy saving potential of this subsector and that this may represent in terms of reducing carbon dioxide emissions. Thormark [59] mentioned that an appropriate choice of construction and building materials can mean a $17 \%$ reduction in the energy of a building. Gonzalez and Navarro [60] mentioned a correct choice of building materials can reduce of almost $30 \% \mathrm{CO}_{2}$ emissions, avoiding the emission of 38 tons of $\mathrm{CO}_{2}$. These authors reported that a building constructed with materials of low environmental impact, will present $\mathrm{CO}_{2}$ emissions of approx. $196 \mathrm{~kg} / \mathrm{m}^{2}$. The appropriate choice of building materials can thus contribute decisively to reduce the energy consumption of the building sector. The energy used for building materials transportation is a factor that contributes to its low environmental performance. Berge [10] presents some energy figures according to the transportation mode (Table 1). Therefore the use of local materials as it happens with earth construction should be prioritize. Earth extraction generally involves the removal of the top layer of the soil, an operation without energy needs since it can be done manually. Some authors [61] compare the carbon dioxide emissions of earth blocks and construction materials used in conventional masonry, showing the good environmental performance of the former (Fig. 4). For a house with three rooms and an area of $92 \mathrm{~m}^{2}$ made with earth walls the values in represent a reduction of 7 tons of

Table 1

Transportation energy [10].

\begin{tabular}{ll}
\hline Transport mode & MJ/ton km \\
\hline Plane & $33-36$ \\
Highway (diesel) & $0.8-2.2$ \\
Railway (diesel) & $0.6-0.9$ \\
Railway (electricity) & $0.2-0.4$ \\
Boat & $0.3-0.9$ \\
\hline
\end{tabular}

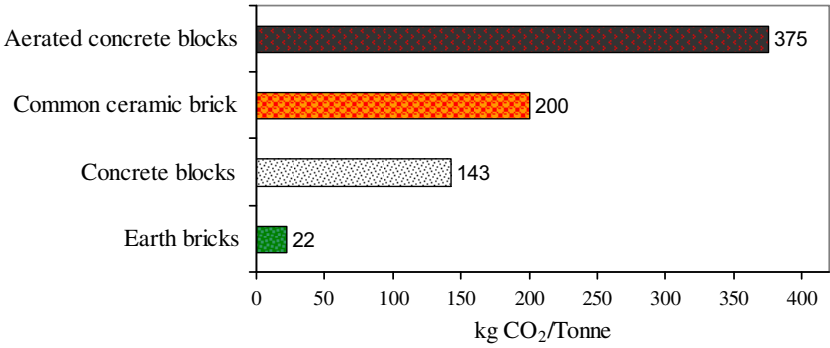

Fig. 4. Embodied carbon in different masonry materials [61].

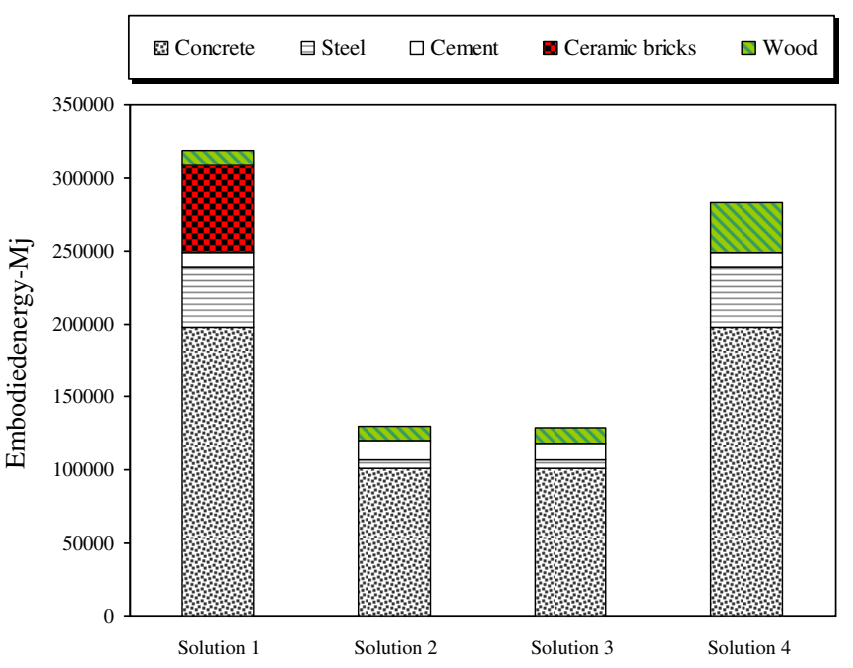

Fig. 5. Embodied energy for four different scenarios [62].

$\mathrm{CO}_{2}$ compared to ceramic brick and a reduction of 14 tones of $\mathrm{CO}_{2}$ if aerated concrete blocks were used. The replacement of only $5 \%$ of concrete blocks used in the UK masonries by earth masonry would mean a reduction in $\mathrm{CO}_{2}$ emissions of approximately 100,000 tons [46]. Lourenço [62] studied the embodied energy (wood, concrete, steel, ceramic bricks and cement) of a single floor building comprising the following variants:

- Solution 1: Building with a reinforced concrete structure, ceramic hollow brick masonry and roof slab using precast reinforced concrete beams and ceramic hollow elements.

- Solution 2: Building with CEB masonry with top concrete beams and wooden roof.

- Solution 3: Building with exterior walls made on rammed earth, interior walls made on adobe and wooden roof.

- Solution 4: Building with a reinforced concrete structure and adobe walls.

This author shows that the embodied energy of earth buildings (Solutions 2 and 3 ) is half the embodied energy of conventional construction (Fig. 5). Shukla et al. [63] studied adobe based buildings observing an embodied energy of $4.75 \mathrm{GJ} / \mathrm{m}^{2}$. According to these authors adobe buildings have the potential to reduce the production of almost 100 tons of $\mathrm{CO}_{2}$ emissions every year. Reddy and Kumar [64] shows that the embodied energy in cement stabilized rammed earth walls increases linearly with the increase in cement content and is in the range of $0.4-0.5 \mathrm{GJ} / \mathrm{m}^{3}$ for cement content in the rage of $6-8 \%$. Table 2 shows that in rammed earth walls stabilized with cement means that carbon embodied goes from 26 to $70 \mathrm{~kg} \mathrm{CO}_{2}$ (Table 2) increasing its environmental impact. Nevertheless, 
Table 2

Carbon embodied in different wall types [65].

\begin{tabular}{ll}
\hline Wall type & $\mathrm{kg} \mathrm{CO}_{2}$ eqv \\
\hline Generic rammed earth & 26 \\
Cement stabilized rammed earth 8\% & 65 \\
Cement stabilized rammed earth 9\% & 70 \\
Brick or stone and blockwork cavity & 71 \\
\hline
\end{tabular}

compressed stabilized earth blocks are more eco-friendly than fired bricks and their manufacture consumes less energy (15 times less) and pollute less than fired bricks (eight times less) [47].

\subsection{Indoor air quality}

While our ancestors lived in buildings made of raw materials free from toxics, nowadays, residential buildings contain a high amount of chemicals and heavy metals, that contaminate indoor air, thus causing several health related problems such as: asthma; itchiness; burning eyes, skin irritations or rashes, nose and throat irritation; nausea; headaches; dizziness; fatigue; reproductive impairment; disruption of the endocrine system; impaired child development and birth defects; immune system suppression and cancer $[66,67]$. Earth construction is not associated with the adverse effects of indoor air volatile organic compounds (VOCs) so the occupants of these buildings have a superior indoor air quality [68]. Another advantage of the indoor air quality of earth buildings relates to its ability to control the relative humidity [69]. Some investigations show that the earth blocks are capable of absorbing 10 times more weight moisture than ceramic bricks (Fig. 6). Earthen structures act as a relative humidity flywheel, equalizing the relative humidity of the external environment with that of the pores within the walls $[10,45]$. Although water can cause the decay of earth materials the fact is that stabilized earth masonry has a good performance to rainfall and even to occasional immersion in water. According to Morton [46] the hygroscopic behavior of construction materials can be more effective in reducing the indoor air relative humidity than the use of ventilation. This author mentioned a study conducted in Britain where it was noted that earth construction is capable of keeping the relative humidity of indoor air between $40 \%$ and $60 \%$, this range being the most suitable for human health purposes. High levels of humidity above $70 \%$, are

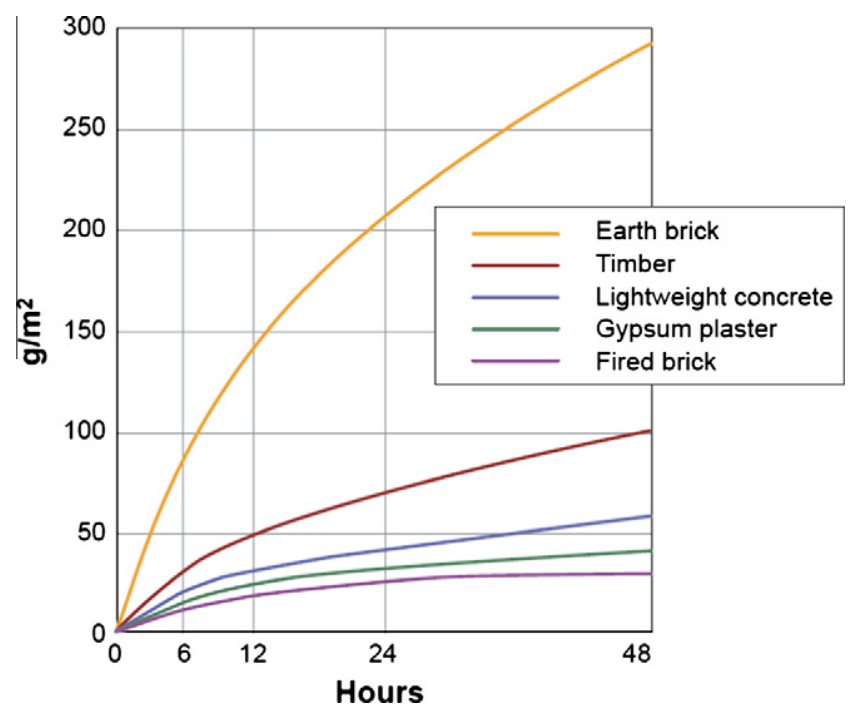

Fig. 6. Weight of moisture absorbed by different materials when relative humidity increases from $50 \%$ to $80 \%$ [69].

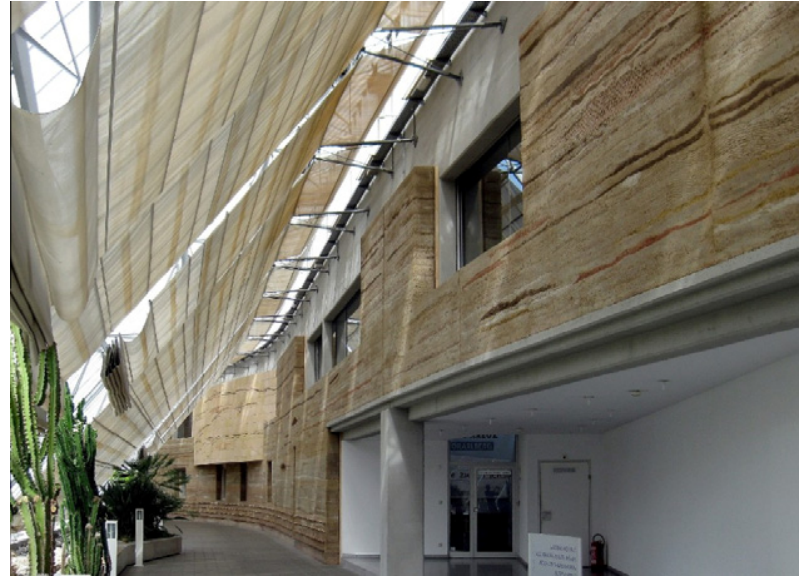

Fig. 7. Rammed earth wall, Hospital of Feldkirch, Austria [10].

responsible for the appearance of molds which can trigger allergic reactions [70]. Relative humidity values above $60 \%$ are associated with the presence of mites and also asthmatic diseases [71]. On the other hand, a relative humidity below $40 \%$ are linked to the syndrome of "sick buildings" typical of very dry indoor air. This leads to a drying of the respiratory mucosa, resulting in respiratory diseases such as tonsillitis, pharyngitis or bronchitis. Therefore, it is easily understood that public health statistics in recent decades show an increase of almost 50\% in the occurrence of health problems from respiratory conditions such as asthma [72]. The Hospital of Feldkirch in Austria in which a $180 \mathrm{~m}$ gallery was built with long sections coated with rammed earth (in some cases up to $6 \mathrm{~m}$ high), with the sole aim of achieving the stabilization of the relative humidity without using of conventional mechanical devices (Fig. 7).

\section{Conclusions}

Earth construction exists since the early agricultural societies, a period whose current knowledge dates from 12,000 to 7000 BC. There are countless cases of earth buildings which were build 1000 years ago and made it to the XXI century. Nowadays, the majority of earth construction is located in less developed countries, unfortunately, the fact that earth construction is associated with low income status is probably one of the most important reasons that explain why less developed countries try to emulate the use of unsustainable construction materials in the majority of the developed countries. Earth construction can also be found in developed ones, where a growing awareness on the importance of this type of construction can be witness nowadays. Although earth construction is cost-effective its economic advantages are dependent on the nature and the amount of binder used in the stabilization process. Investigations show that soil stabilization with gypsum shows to be much more cost effective than with Portland cement. Earth construction is associated with low embodied energy, low carbon dioxide emissions and very low pollution impacts. The use of cement for soil stabilization increases embodied energy, therefore, further studies about the environmental impacts of earth construction stabilized with non-Portland cement binders are needed. Investigations about soil stabilization with lime and pozzolanic aluminosilicate wastes should also be analyzed. Nevertheless, earth construction in seismic regions needs to be associated with a reinforced concrete structure reducing its eco-efficiency. Earth construction is also responsible for an indoor air relative humidity beneficial to the human health; therefore, 
earth construction has clear competitive advantages in the field of sustainability over conventional construction assuring it a promising future in the years to come.

\section{References}

[1] Stern N. Stern review on economics of climate change. Cambridge University Press; 2006.

[2] IPCC climate change 2007 - impacts, adaptation and vulnerability. Intergovernmental panel on climate change; 2007 [ISBN-13: 9780521705974].

[3] United Nations - acting on climate change: the UN system delivering as one. DPI/2526; 2008.

[4] World Watch Institute - State of the World; 2009 [ISBN: 978-0-393-33418-0]

[5] Dobbs R. Prime numbers: megacities. Foreign policy; 2010. <http:// www.foreignpolicy.com/articles/2010/08/16/prime_numbers_megacities $>$.

[6] Gartner E, MacPhee E. A physico-chemical basis for novel cementitious binders. Cem Concr Res 2011;41:736-49.

[7] Jiménez Delgado MC, Guerrero IC. The selection of soils for unstabilised earth building: a normative review. Constr Build Mater 2007;21:237-51.

[8] Minke G. Building with earth, design and technology of a sustainable architecture. Basel- Berlin-Boston: Birkhäuser - Publishers for Architecture; 2006.

[9] Pollock S. Ancient mesopotamia. Cambridge University Press; 1999.

[10] Berge B. The ecology of building materials. 2 ed. Architectural Press, Elsevier Science: 2009 [ISBN 978-1-85617-537-1].

[11] Jaquin PA. Analysis of historic rammed earth construction. PhD thesis. Durham Universit, United Kingdom; 2008.

[12] Alexandra S. Architecture and earth construction in Piaui: Research, characterization and analysis. Master thesis, Federal University of Piauí, Brasil; 2006.

[13] Helfritz H. Land without shade. J Roy Central Asian Soc 1937;24(2):201-16.

[14] Guillaud H. Characterization of earthen materials. In: Avrami E, Guillaud H, Hardy M, editors. Terra literature review-an overview of research in earthen architecture conservation. Los Angeles (United States): The Getty Conservation Institute; 2008. p. 21-31.

[15] Houben H, Doat P, Fontaine L, Anger R, Aedo W, Olagnon C, et al. Builders grains - a new pedagogical tool for earth architecture education. In: 5th International conference on building with earth - LEHM 2008, Weimar Germany; 2008. p. 51-7.

[16] Schroeder H, Rohlen U, Jorchel S. Education and vocational training in building with earth in Germany. In: 5th International conference on building with earth - LEHM 2008, Weimar, Germany; 2008. p. 193-7.

[17] Schroeder H, Volhard F, Rohlen U, Ziegert C. The "Lehmbau Regeln" in 2008 - a review after 10 years of use in practice. In: 5th International conference on building with earth - LEHM 2008, Weimar, Germany; 2008. p. 13-21.

[18] Maniatidis V, Walker P. A review of rammed earth construction. University of Bath; 2003.

[19] Delgado MC, Guerrero IC. Earth building in spain. Constr Build Mater 2006;20:679-90.

[20] Keable J. Rammed earth structures. A code of practice. London, UK: Intermediate Technology; 1996

[21] Shittu T. Earth construction in Nigeria: challenges and prospects. In: 5th International conference on building with earth - LEHM 2008, Weimar, Germany; 2008. p. 41-7.

[22] Graham T. Wattle and daub: craft, conservation and Wiltshire case study Master thesis, University of Bath, United Kingdom; 2004. <http:/| www.tonygraham.co.uk/house_repair/Wattle_Daub_Conservation.pdf> [accessed 22.06.11].

[23] Pinto J, Varum H, Cruz D, Sousa D, Morais P, Tavares P, et al. Characterization of traditional tabique constructions in Douro North valley region. WSEAS Trans Environ Develop 2010;6:105-14.

[24] Quagliarini E, Stazi A, Pasqualini E, Fratalochi E. Cob construction in Italy: some lessons from the past. Sustainability 2010; 2: 3291-3308. <http:// www.mdpi.com/2071-1050/2/10/3291/pdf> [accessed 22.06.11].

[25] Quagliarini E, Lenci S, Iori M. Mechanical properties of adobe walls in a Roman republican domus at Suasa. J Cultural Heritage 2010;11:130-7.

[26] Rogers CDF, Smalley IJ. The adobe reaction and the use of loess mud in construction. Constr Build Mater 1995;40:137-8.

[27] Neumann JV, Bernales JB, Blondet M. Seismic resistance of adobe masonry. Pontificia University Católica of Peru; 1984. p. 19.

[28] Quagliarini E, Lenci S. The influence of natural stabilizers and natural fibres on the mechanical properties of ancient Roman adobe bricks. J Cultural Heritage 2010;11:309-14

[29] Mukerji K. Soil block presses. Publication of Deutsches Zentrum fr Entwicklungstechnologien - GATE, a Division of the Deutsche Gesellschaft $\mathrm{fr}$ Technische Zusammenarbeit (GTZ) GmbH; 1986. p. 38.

[30] Webb D. Stabilized soil construction in Kenya. In: Proceedings, international conference on economical housing in developing countries, UNESCO, Paris; 1983.

[31] Burroughs S. Soil property criteria for rammed earth stabilization. J Mater Civil Eng 2008:265-73.

[32] Vilane B. Assessment of stabilisation of adobes by confined compression tests. Biosyst Eng 2010;106:551-8.
[33] Binici H, Aksogan O, Shah T. Investigation of fibre reinforced mud brick as a building material. Constr Build Mater 2005;19:313-8.

[34] Morel JC, Pkla A. A model to measure compressive strength of compressed earth blocks with the 3 points bending test. Constr Build Mater 2002;16:303-10.

[35] Piattoni Q, Quagliarini E, Lenci S. Experimental analysis and modelling of the mechanical behaviour of earthen bricks. Constru Build Mater 2011;25:2067-75.

[36] Silva B, Correia J, Nunes F, Tavares P, Varum H, Pinto J. Bird nest construction - lessons for building with earth. WSEAS Trans Environ Develop 2010;6:95-104.

[37] Gomes M, Lopes M, De Brito J. Seismic resistance of earth construction in Portugal. Eng Struct 2011;33:932-41.

[38] Bui Q-B, Hans S, Morel J-C, Do A-P. First exploratory study on dynamic characteristics of rammed earth buildings. Eng Struct 2011;33:3690-5.

[39] MacDougall C. Natural building materials in mainstream construction: lessons from the UK. J Green Build 2008;3:3-14

[40] Goodhew S, Griffiths R. Sustainable earth walls to meet the buildings regulations. Energy Build 2005;37:451-9.

[41] Desborough N, Samant S. Is straw a viable building material for housing in the United Kingdom? Sustainability 2009;2:368-74.

[42] Williams C, Goodhew S, Griffiths R, Watson L. The feasibility of earth block masonry for building sustainable walling in the United Kingdom. J Build Appraisal 2010;6:99-108.

[43] Pinto J, Paiva A, Varum H, Costa A, Cruz D, Pereira S, et al. Corn's cob as a potential ecological thermal insulation material. Energy Build 2011;43:1985-90.

[44] Martin S, Mazarron F, Canas I. Study of thermal environment inside rura houses of Navapalos (Spain): The advantages of reuse buildings of high thermal inertia. Constr Build Mater 2010;24:666-76.

[45] Allison D, Hall M. Hygrothermal analysis of a stabilised rammed earth test building in the UK. Energy Build 2010;42:845-52.

[46] Morton T. Earth masonry - design and construction guidelines. HIS BRE Press; 2008 [ISBN 978-1-86081-978-0].

[47] Zami M, Lee A. Stabilised or un-stabilised earth construction for contemporary urban housing? In: 5th International conference on responsive manufacturing 'Green Manufacturing'. Ningbo Higher Education Park, the University of Nottingham Ningbo, China, 11-13 January; 2010.

[48] UNCHS. Building materials and health. HS/459/97E; 1997 [ISBN -92-1-131338-4].

[49] Little B, Morton T. Building with earth in Scotland: Innovative design and sustainability. Scottish Executive Central Research Unit, Edinburgh, Scotland; 2001.

[50] Eires R, Camões A, Jalali S. Eco-efficient Mortars with Enhanced Mechanical, Durability and Bactericidal Performance. International Congress Sustainable Construction, Materials and Practices - Challenge of the Industry for the New Millennium: Edited by Luis Bragança, Manuel Pinheiro, Said Jalali, Ricardo Mateus, Rogério Amoêda, Manuel Correia Guedes. Portugal SB07, Lisboa; 2007. p. 880-6 [ISBN 978-1- 58603-785-7].

[51] Heathcote KA. Durability of earthwall buildings. Constr Build Mater 1995;9:185-9.

[52] Ogunye FO, Boussabaine H. Diagnosis of assessment methods for weatherability of stabilized compressed soil blocks. Constr Build Mate 2002;16:163-72.

[53] Bui QB, Morel JC, Venkatarama BV, Ghayad W. Durability of rammed earth walls exposed for 20 years to natural weathering. Build Environ 2008;44:912-9.

[54] Zami M, Lee A. Economic benefits of contemporary earth construction in low-cost urban housing - state-of-the-art review. J Build Appraisal 2010;5:259-71.

[55] Sanya T. Living earth. The sustainability of earth architecture in Uganda. PhD thesis. The oslo school of architecture and design, Norway; 2007.

[56] WEO. World Energy Outlook. IEA; 2009 [ISBN 978-92-64-06130-9].

[57] UN, Energy for a sustainable future. The Secretary-Generaĺs advisory group on energy and climate change; 2010.

[58] OCDE. Environmental sustainable building - challenges and policies. Paris, France; 2003. p. 194

[59] Thormark C. The effect of material choice on the total energy need and recycling potential of a building. Build Environ 2006;41:1019-26.

[60] Gonzalez M, Navarro J. Assessment of the decrease of $\mathrm{CO}_{2}$ emissions in the construction field through the selection of materials. Build Environ 2006;41:902-9.

[61] Morton T, Stevenson F, Taylor B, Smith C. Low cost earth brick construction: Monitoring and evaluation. Arc. Architects; 2005 [ISBN 0-9550580-0-7].

[62] Lourenço PI. Earth constructions. Master thesis, UTL-IST, Lisbon, Portugal 2002.

[63] Shukla A, Tiwari G, Sodha MS. x Embodied energy analysis of adobe house. Renew Energy 2008;34:755-61.

[64] Reddy B, Kumar P. Embodied energy in cement stabilized rammed earth walls. Energy Build 2010;42:380-5.

[65] Lax C. Life cycle assessment of rammed earth. Master thesis, University of Bath, United Kingdom; $2010 . \quad<$ http://www.ebuk.uk.com/docs/ Dissertation_Clare_Lax.pdf> [accessed 22.06.11].

[66] Chikara H, Iwamoto S, Yoshimura T. Indoor air pollution of volatile organic compounds: indoor/outdoor concentrations, sources and exposures. Nippon eiseigaku zasshi. Jap J Hygiene 2009;64:683-8. 
[67] Reboux G, Bellanger A-P, Roussel S, Grenouillet F, Millon L. Moulds in dwellings: health risks and involved species. Archives des Maladies Professionnelles et de l'Environnement 2011;72:352-62.

[68] Wargocki P, Wyon D, Baik Y, Clausen G, Fanger P. Perceived air quality, sick building syndrome (SBS) symptoms and productivity in an office with two different pollution loads. Indoor Air 1999;9:165-79.

[69] Minke G. Earth construction handbook. The building material earth in the modern architecture. Southampton, UK: WIT Press; 2000.
[70] Arundel A, Sterling E, Biggin J, Sterling T. Indirect health effects of relative humidity in indoor environments. Environ Health Perspect 1986;65:351-61.

[71] Howieson S. Housing and asthma. London: Spon Press; 2005 [ISBN 0-41533646-5].

[72] Heerwagen J. Green buildings, organizational success and occupant productivity. Build Res Inform 2000;28:353-67. 